\title{
ANTIMICROBIAL \& ANTI-DIABETIC EFFECT OF TRITERPENE BARRINGOTOGENOL C GLYCOSIDES ISOLATED FROM AERIAL PART OF MEDICAGOSATIVA L.(ALFALFA) (FAMILY FABACEAE) CULTIVATED IN EGYPT.
}

\section{BY}

Said A.Omar ${ }^{1}$, HalaSh. Mohammed ${ }^{2}$, Marwa Abd-Elaziz $^{3} \&$ Maie O.A. Mohamed ${ }^{4}$

\section{From}

${ }^{1}$ Department of Plant Research Institute,Giza,Egypt.

${ }^{2}$ Department of Pharmacognosy, Faculty of Pharmacy (Girls) Al -Azhar-University, Cairo, Egypt.

${ }^{3}$ The Regional Center for Mycology and Biotechnology (RCMB),AlAzhar-University, Cairo, Egypt.

${ }^{4}$ Pharmacist at Al-Tawfeek Polyclinic complex.

\section{ABSTRACT}

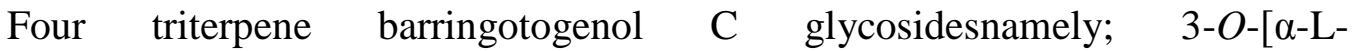
rhamnopyranosyl (1-4) $\beta$-D-glucopyranosyl(1-4)- $\beta$-D-glucouronopyranoside]-21- $O$ - $\alpha$-Lrhamnopyranoside barringotogenolC(I), 3 - $O$ - $[\alpha$-L-rhamnopyranosyl(1-4) $\quad \beta$ glucopyranosyl(1-4) $\beta$-D-galactopyranosyl] $21-\mathrm{O}-\alpha-\mathrm{L}-$ rhamnopyranosidebarringotogenolC(II),3- $O$-[ $[\beta$-D-glucopyranosyl(1-4) $\quad \beta$-Dglucopyranosyl $\quad(1-4) \quad \beta-\mathrm{D} \quad$ glucuronopyranoside] $21-O-\alpha-\mathrm{L}-$ rhamnopyranosidebarringotogenolC(III),3- $O$-[ $\beta$-D-glucopyranosyl(1-6) $\beta$-D-

glucopyranosyl]21-O- $\beta$-D-glucopyranosidebarringotogenol $\mathbf{C}(\mathbf{I V})$, Were isolated for the first time from the aerial part of Medicago sativa L.All compounds (I-IV) were identified by combination of spectroscopic methods (ID \& 2DNMR) and compared with literature data.The extracts (Methanol \& Dichloromethane) \& isolated pure compounds were evaluated in vitro for their antimicrobial activity against Streptococcus pneumoniae (RCMB010010), Staphylococcus aureus (RCMB010028) (Gram+vestrain bacteria), Pseudomonas aeuroginosa (RCMB010043), Escherichia coli (RCMB010052) (Gram -vestrainbacteria) and Antifungal activity against Aspergillus fumigatus (RCMB02568) and Candida albicans (RCMB05036). Furthermore, theywere evaluated for their in vitro Anti-diabetic activity using $\alpha$-Amylase inhibition method.

\section{Introduction}

Alfalfa is a perennial flowering forage herb plant in Family Fabaceae and botanically known as Medicago sativa L.(Benson1965) (Alfalfa) Medicago sativa L. is a widely cultivated, environmentally tolerant forage crop.The Alfalfa plant is beneficial 
to both humans $\&$ animals. The whole plant material contains many active constituents including steroidal saponins, sterols,coumarins, flavonoids, phenolic compounds isoflavones,coumesterolanalogues (Duke et al;1985).Medicago sativa L. has received considerable attention due to itstheraputic potential as anti-inflammatory, reducing elevated cholesterol levels in blood, anti-oxidant activities, antimicrobial activities, antidiabetic, anticancer (Ratheeet al;2009)

\section{Aim of the study}

In this study, we describe the isolation of four compounds (I-IV) and their subsequent structural determination by spectroscopic analysis, in addition to the investigation of the Antimicrobial activity of barringotogenol $\mathrm{C}$ glycosides from (alfalfa) Medicagosativa L. against Gram+ve, -ve\&fungi, also investigate the in vitro Anti-diabetic activity by $\alpha$-amylase inhibition.

\section{Materialsand Methods}

General experimental procedures: The ${ }^{1} \mathrm{H}$ and ${ }^{13} \mathrm{CNMR}$ measurements were obtained with Bruker Spectrometer operating at $850 \mathrm{MHz}\left(\right.$ for ${ }^{1} \mathrm{H}$ ) and $213 \mathrm{MHz}$ (for ${ }^{13} \mathrm{C}$ ) in DMSO-d6 solution and the chemical shifts were expressed in $\delta(\mathrm{ppm})$ with reference toTMS and coupling constant $(J)$ in Hertz.Mass spectrometry (MS):AESI-MsDouble focusing sector field Finnigan MAT90 with ESI-II ion source for ESI-MS (Finnigan,Bremen and Germany) (The analysis was done in ICAS-institute for spectrochemistry, Dortmund and Germany) and HRESI-MS analysis was run on a LTQFT-MS spectrometer (ThermoElectron, Germany).Polyamide 6S (Riedel De HaenAG, Hannover) and Silica gel G(Merckgrade 60, mesh Merck) were used for open column chromatography.TLC was carried out on percoated silica gel 60 F254 (Merck) plates. Developed chromatogram was visualized by spraying with10-15\% Ethanol/H2SO4 at $120^{\circ} \mathrm{C}$ ).Plant material;Fresh (aerial part) of Medicago sativa L. (alfalfa) were collected from ISMAELIA governorate (November 2014). The identity of the plant was established by Prof. Dr Said Ahmed Mohamed Omar, Head Researcher of Plant Pathology Research Institute.The plant material after being dried then grounded \&kept in tight closed container.

\section{Extraction}

The dry ground powder aerial part of Medicago sativa L. (alfalfa) (4Kg) was extracted with $70 \%$ alcohol under reflux for several times. The total extract was dried under reduced pressure to give $(650 \mathrm{gm})$ and defatted with dichloromethane under reflux(175gm).The residue after defatting was suspended in least of water and absolute ethanol was added to precipitate inorganic salts and sugars then filter,the filtrate was evaporated under reduced pressure. The residue was applied on polyamide column eluted with $\mathrm{H} 2 \mathrm{O}$ and decrease polarity by adding Methanol until 100\% Methanol to obtain 7 collective fractions; Fraction2-7were successively separated on series of column silica gel G-60 by using Petroleum ether: ethyl acetate system to the offered four 
compounds.Compound (I) 50mg, compound (II) 15mg, compound (III)20mg, compound (IV) $20 \mathrm{mg}$.

\section{Acid Hydrolysis(I-IV)}

Each compound (3-4 mg) was treated with $2 \mathrm{~N} \mathrm{Hcl}$ in $50 \%$ aqueous methanol for $2 \mathrm{hr}$ at $100^{\circ} \mathrm{c}$.After evaporation of methanol cold aqueous hydrolysate was exhaustively extracted with ethyl acetate in separating funnel.Aglycones were identified in the ethyl acetate fraction by Co-PC alongside authentic aglycones or using different spectroscopic analysis. The aqueous phase was neutralized with 5\% sodium bicarbonate and used for investigation of the sugar moieties on Co-PC against authentic samples using aniline hydrogen phthalate as a spray reagant. Which indicate the sugars to be rhamnose, glucuronic acid and glucose for compound (I), rhamnose, glucose and galactose for compound (II), glucose, rhamnose and glucuronic acid for compound (III) and glucose for compound (IV).

\section{Results and Discussion}

Table (1): $1 \mathrm{D}^{1}{ }^{1} \mathrm{HNMR}, \mathrm{DMSO}-\mathrm{d}_{6}-850,213 M H Z, D E P T-135,213 M H Z$ and 2D(HMQC, COSY,HMBC)NMR data of compound (I)

\begin{tabular}{|c|c|c|c|c|c|c|}
\hline C no & ${ }^{1} \mathbf{H N M R}^{\mathrm{a}}$ & ${ }^{13} \mathrm{CNMR} / \mathrm{HMQC}$ & DEPT $^{b}$ & COSY & \multicolumn{2}{|c|}{ HMBC $^{\mathrm{c}}$} \\
\hline & & & & & ${ }^{2} \mathbf{J}_{\mathrm{CH}}$ & ${ }^{3} \mathbf{J}_{\mathrm{CH}}$ \\
\hline 1 & $1.09 / 1.18(\mathrm{~m})$ & $41.2(\mathrm{t})$ & $\mathrm{CH} 2$ & $\begin{array}{l}\mathrm{H}-1 \mathrm{~b}, \mathrm{H}_{2}-2 \\
\mathrm{H}-1 \mathrm{a}, \mathrm{H}_{2}-2\end{array}$ & $\mathrm{C} 2, \mathrm{C} 10$ & $\mathrm{C}-25$ \\
\hline 2 & $1.31 / 1.45(\mathrm{~m})$ & $25.5(\mathrm{t})$ & $\mathrm{CH} 2$ & $\begin{array}{c}\mathrm{H}-2 \mathrm{~b}, \mathrm{H}_{2}-1, \mathrm{H}-3 \\
\mathrm{H}-2 \mathrm{~b}, \mathrm{H} 3\end{array}$ & $\mathrm{C} 3, \mathrm{C} 1$ & $\begin{array}{l}\mathrm{C} 4 \\
\mathrm{C} 10\end{array}$ \\
\hline 3 & $3.58(\mathrm{~m})$ & $90.1(\mathrm{~d})$ & $\mathrm{CH}$ & $\mathrm{H}_{2}-2, \mathrm{H}-1 \mathrm{a}$ & $\mathrm{C} 2, \mathrm{C} 4$ & - \\
\hline 4 & - & $36.9(\mathrm{~s})$ & - & - & - & - \\
\hline 5 & $0.79(\mathrm{~d}, J=9.35 \mathrm{~Hz})$ & $55.1(\mathrm{~d})$ & $\mathrm{CH}$ & H-6a & C-6 & C-9,C-3 \\
\hline 6 & $1.45 / 1.52(\mathrm{~m})$ & $17.8(\mathrm{t})$ & $\mathrm{CH} 2$ & $\begin{array}{c}\mathrm{H}-6 \mathrm{~b}, \mathrm{H} 2-7, \mathrm{H} 5 \\
\mathrm{H}-6 \mathrm{a}, \mathrm{H} 5\end{array}$ & C-7,C-5 & $\mathrm{C} 8, \mathrm{C} 10$ \\
\hline 7 & $1.31 / 1.67(\mathrm{~m})$ & $32.5(\mathrm{t})$ & $\mathrm{CH} 2$ & $\begin{array}{l}\mathrm{H}-7 \mathrm{a}, \mathrm{H}_{2}-6 \\
\mathrm{H}-7 \mathrm{~b}, \mathrm{H}-6 \mathrm{~b}\end{array}$ & C-6,C-8 & - \\
\hline 8 & - & $41.6(\mathrm{~s})$ & - & - & - & - \\
\hline 9 & $1.66(\mathrm{~m})$ & $46.8(\mathrm{~d})$ & $\mathrm{CH}$ & $\mathrm{H}_{2}-11$ & $\begin{array}{c}\text { C-8, } \\
\text { C-10,C-11 }\end{array}$ & $\begin{array}{c}\text { C-12,C-25, } \\
\text { C-26 }\end{array}$ \\
\hline 10 & - & $35.8(\mathrm{~s})$ & - & - & - & - \\
\hline 11 & $2.00(\mathrm{~m})$ & $23.2(\mathrm{t})$ & $\mathrm{CH} 2$ & $\begin{array}{l}\mathrm{H}-11 \mathrm{~b}, \mathrm{H}-9, \mathrm{H}_{12} \\
\mathrm{H}-11 \mathrm{a}, \mathrm{H}-9, \mathrm{H}_{12}\end{array}$ & C-9,C-12 & C-13,C-8 \\
\hline 12 & 5.17 (brs) & $121.6(d)$ & $\mathrm{CH}$ & $\mathrm{H}_{2}-11$ & $\mathrm{C} 11, \mathrm{C} 13$ & $\begin{array}{c}\mathrm{C} 18, \mathrm{C} 19, \\
\text { C9,C14 }\end{array}$ \\
\hline 13 & - & $144.1(\mathrm{~s})$ & - & - & - & - \\
\hline 14 & - & $42.8(\mathrm{~s})$ & - & - & - & - \\
\hline 15 & $1.45(\mathrm{~m})$ & $38.0(\mathrm{t})$ & $\mathrm{CH} 2$ & $\mathrm{H}-15 \mathrm{a}, \mathrm{b}, \mathrm{H}_{2}-16$ & C-14,C-16 & - \\
\hline 16 & $5.06(\mathrm{OH})$ & $68.0(\mathrm{~d})$ & $\mathrm{CH}$ & $\mathrm{H}-16 \mathrm{a}, \mathrm{bH}_{2}-15$ & C-15,C-17 & C-18 \\
\hline 17 & - & $43.0(\mathrm{~s})$ & - & - & - & - \\
\hline 18 & $3.08(\mathrm{t})$ & $44.5(\mathrm{~d})$ & $\mathrm{CH}$ & $\mathrm{H}_{2}-19$ & C-17 & C-14 \\
\hline 19 & $2.98(\mathrm{~d}, J=8.5)$ & $46.0(\mathrm{t})$ & $\mathrm{CH} 2$ & H-19a,b,H-18 & C-18,C-20 & - \\
\hline 20 & - & $35.8(\mathrm{~s})$ & - & - & - & - \\
\hline 21 & $3.85(\mathrm{~d}, J=9.35 \mathrm{~Hz})$ & $90.5(\mathrm{~d})$ & $\mathrm{CH}$ & H-22 & $\mathrm{C}-22$ & C-19 \\
\hline
\end{tabular}




\begin{tabular}{|c|c|c|c|c|c|c|}
\hline 22 & $5.15(\mathrm{OH})$ & $74.0(\mathrm{~d})$ & $\mathrm{CH}$ & $\mathrm{H}-21$ & $\mathrm{C}-21$ & $\mathrm{C}-16$ \\
\hline 23 & $1.29(\mathrm{~s})$ & $22.3(\mathrm{q})$ & CH3 & - & C-4 & $\mathrm{C}-3$ \\
\hline 24 & $0.75(\mathrm{~s})$ & $15.3(\mathrm{q})$ & $\mathrm{CH} 3$ & - & $\mathrm{C}-4$ & C-3,C-5 \\
\hline 25 & $0.88(\mathrm{~s})$ & $14.2(\mathrm{q})$ & $\mathrm{CH} 3$ & - & $\mathrm{C}-10$ & - \\
\hline 26 & $0.85(\mathrm{~s})$ & $15.4(q)$ & $\mathrm{CH} 3$ & - & $\mathrm{C}-8$ & C-7,C-10 \\
\hline 27 & $1.79(\mathrm{~s})$ & $22.1(\mathrm{q})$ & CH3 & - & $\mathrm{C}-14$ & $\mathrm{C}-13$ \\
\hline 28 & $3.21(\mathrm{~m})$ & $59.8(\mathrm{t})$ & $\mathrm{CH} 2$ & - & $\mathrm{C}-17$ & - \\
\hline 29 & $1.06(\mathrm{~s})$ & $28.3(\mathrm{q})$ & $\mathrm{CH} 3$ & - & $\mathrm{C}-20$ & $\begin{array}{l}\text { C-21- } \\
\text { Me-30 }\end{array}$ \\
\hline 30 & $0.97(\mathrm{~s})$ & $16.6(q)$ & $\mathrm{CH} 3$ & - & $\mathrm{C}-20$ & $\begin{array}{c}\mathrm{C} 21- \\
\mathrm{Me}-29\end{array}$ \\
\hline \multicolumn{7}{|c|}{ Glucuronic Acid } \\
\hline 1 & $4.76(\mathrm{~d}, J=6.8 \mathrm{~Hz})$ & $99.9(\mathrm{~d})$ & $\mathrm{CH}$ & - & C1-Glu A & $\mathrm{C}-3$ \\
\hline 2 & - & 72.3 & $\mathrm{CH}$ & - & - & - \\
\hline 3 & - & $74.6(d)$ & $\mathrm{CH}$ & - & - & - \\
\hline 4 & - & $77.4(\mathrm{~d})$ & $\mathrm{CH}$ & - & - & - \\
\hline 5 & - & 75.7 & $\mathrm{CH}$ & - & - & - \\
\hline 6 & - & $170.4(\mathrm{~s})$ & - & - & - & - \\
\hline \multicolumn{7}{|c|}{ Glucose } \\
\hline $\mathbf{1}$ & $4.80(\mathrm{~d}, J=6 \mathrm{~Hz})$ & $100.1(\mathrm{~d})$ & $\mathrm{CH}$ & - & $\begin{array}{c}\text { C1 } \\
\text { (glu) }\end{array}$ & C-4(Glu- A) \\
\hline 2 & - & $72.4(\mathrm{~d})$ & $\mathrm{CH}$ & - & - & - \\
\hline 3 & - & $74.5(\mathrm{~d})$ & $\mathrm{CH}$ & - & - & - \\
\hline 4 & - & $76.6(d)$ & $\mathrm{CH}$ & - & - & - \\
\hline 5 & - & 76.4(d) & $\mathrm{CH}$ & - & - & - \\
\hline 6 & & $60.1(\mathrm{q})$ & $\mathrm{CH} 2$ & - & - & - \\
\hline \multicolumn{7}{|c|}{ Rhamnose-I } \\
\hline $\mathbf{1}$ & 5.00 (brs) & $100.3(d)$ & $\mathrm{CH}$ & - & $\begin{array}{c}\text { C-1 } \\
\text { (Rham-II) }\end{array}$ & $\mathrm{C}-21$ \\
\hline 2 & - & $70.5(d)$ & $\mathrm{CH}$ & - & - & - \\
\hline 3 & - & $70.6(d)$ & $\mathrm{CH}$ & - & - & - \\
\hline 4 & - & $74.0(\mathrm{~d})$ & $\mathrm{CH}$ & - & - & - \\
\hline 5 & - & $69.3(\mathrm{~d})$ & $\mathrm{CH}$ & - & - & - \\
\hline 6 & $1.17(\mathrm{~d}, J=6.8 \mathrm{~Hz})$ & $17.9(q)$ & $\mathrm{CH} 3$ & - & - & - \\
\hline \multicolumn{7}{|c|}{ Rhamnose-II } \\
\hline 1 & 4.94 (brs) & $99.9(\mathrm{~d})$ & $\mathrm{CH}$ & - & $\begin{array}{c}\text { C1 } \\
\text { (Rham-I) }\end{array}$ & $\begin{array}{c}\text { C4 } \\
\text { (glu) }\end{array}$ \\
\hline 2 & - & 70.5 (d) & $\mathrm{CH}$ & - & - & - \\
\hline 3 & - & $70.6(d)$ & $\mathrm{CH}$ & - & - & - \\
\hline 4 & - & $74.0(\mathrm{~d})$ & $\mathrm{CH}$ & - & - & - \\
\hline 5 & & $68.7(\mathrm{~d})$ & - & & & \\
\hline 6 & $1.18(\mathrm{~d}, J=7.6 \mathrm{~Hz})$ & $17.9(q)$ & $\mathrm{CH} 3$ & - & - & - \\
\hline
\end{tabular}

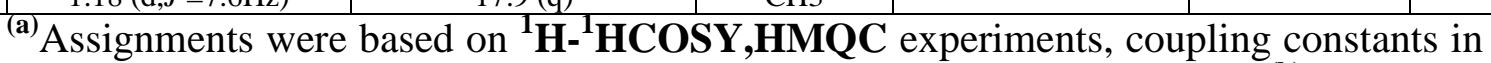
Hertz are given in parentheses; (s): singlet (d): doublet m: multiplet . ${ }^{(b)}$ DEPT, CMultiplicities were established by DEPT experiments, $\mathrm{s}=\mathrm{c}, \mathrm{d}=\mathrm{CH}, \mathrm{t}=\mathrm{CH} 2, \mathrm{q}=$ CH3. ${ }^{(\mathbf{c})}$ The Correlations in $\mathbf{H M B C}$ have been shownfrom protons to carbo 
Table(2): ${ }^{1} \mathrm{HNMR \&}{ }^{13} \mathrm{CNMR}$ (DMSO-d6 -850,213MHZ) data of compoundsII,III\& IV

\begin{tabular}{|c|c|c|c|c|c|c|}
\hline \multicolumn{3}{|c|}{ II } & \multicolumn{2}{|c|}{ III } & \multicolumn{2}{|c|}{ IV } \\
\hline C no & ${ }^{1}$ HNMR & ${ }^{13} \mathrm{CNMR}$ & ${ }^{1}$ HNMR & ${ }^{13}$ CNMR & ${ }^{1}$ HNMR & ${ }^{13}$ CNMR \\
\hline $\mathbf{1}$ & - & 39.9 & - & 41.6 & - & 40.1 \\
\hline 2 & - & 25.6 & - & 25.9 & - & 25.9 \\
\hline 3 & $3.58(\mathrm{~m})$ & 90.1 & $3.15(\mathrm{~m})$ & 90.5 & $\begin{array}{c}3.17 \mathrm{dd} \\
(11.9,3.4)\end{array}$ & 90.5 \\
\hline 4 & - & 41.2 & - & 40.3 & - & 40.2 \\
\hline 5 & $0.79 \mathrm{~d}(9.4)$ & 55.3 & $0.79 \mathrm{~d}(9.3)$ & 55.7 & - & 55.7 \\
\hline 6 & $1.4 / 1.5(\mathrm{~m})$ & unresolved & - & 18.3 & - & 18.3 \\
\hline 7 & - & 32.6 & - & 33.0 & - & 33.0 \\
\hline 8 & - & 41.6 & - & 42.1 & - & 41.6 \\
\hline 9 & - & 46.8 & - & 46.5 & - & 47.3 \\
\hline 10 & - & 38.1 & - & 37.4 & - & 38.5 \\
\hline 11 & - & 25.0 & - & 25.4 & - & 25.4 \\
\hline 12 & 5.17 (brs) & 121.6 & 5.17 brs & 122.0 & $5.17 \mathrm{brs}$ & 122.0 \\
\hline 13 & - & 144.1 & - & 144.5 & - & 144.5 \\
\hline 14 & - & 43.0 & - & 43.5 & - & 43.2 \\
\hline 15 & - & 35.8 & $1.66 \mathrm{~d}(8.5)$ & 36.2 & - & 36.2 \\
\hline 16 & - & 68.0 & $4.49 \mathrm{brs}$ & 69.1 & $4.47 \mathrm{brs}$ & 69.1 \\
\hline 17 & - & 46.8 & - & 47.2 & - & 47.2 \\
\hline 18 & - & 42.8 & - & 43.2 & - & 42.1 \\
\hline 19 & - & 48.6 & - & 47.3 & - & 49.0 \\
\hline 20 & - & 36.9 & - & 37.4 & - & 37.4 \\
\hline 21 & $4.02 \mathrm{~d}(8.5)$ & 90.5 & 3.91 & 90.9 & $\begin{array}{c}3.96 \mathrm{~d} \\
(9.4)\end{array}$ & 90.8 \\
\hline 22 & $3.85 \mathrm{~d}(8.5)$ & 74.0 & $3.85 \mathrm{~d}(9.5)$ & 74.5 & $\begin{array}{c}3.83 d \\
(9.4)\end{array}$ & 74.5 \\
\hline 23 & $1.09(\mathrm{~s})$ & 28.3 & $1.12(\mathrm{~s})$ & 28.7 & $1.12(\mathrm{~s})$ & 28.7 \\
\hline 24 & $0.75(\mathrm{~s})$ & 15.3 & $0.75(\mathrm{~s})$ & 15.9 & $0.76(\mathrm{~s})$ & 15.9 \\
\hline 25 & $0.88(\mathrm{~s})$ & 15.4 & $0.89(\mathrm{~s})$ & 14.5 & $0.89(\mathrm{~s})$ & 15.7 \\
\hline 26 & $0.85(\mathrm{~s})$ & 16.6 & $0.85(\mathrm{~s})$ & 17.0 & $0.85(\mathrm{~s})$ & 17.0 \\
\hline 27 & $1.12(\mathrm{~s})$ & 25.5 & $1.14(\mathrm{~s})$ & 21.2 & $1.14(\mathrm{~s})$ & 25.9 \\
\hline 28 & $3.2(\mathrm{~m})$ & 68.0 & - & 68.4 & $\begin{array}{l}3.45 \mathrm{~d} \\
(10.2)\end{array}$ & 68.4 \\
\hline 29 & $1.06(\mathrm{~s})$ & 30.2 & $1.06(\mathrm{~s})$ & 30.6 & $1.06(\mathrm{~s})$ & 30.6 \\
\hline 30 & $0.97(\mathrm{~s})$ & 20.3 & $0.97(\mathrm{~s})$ & 20.5 & $0.97(\mathrm{~s})$ & 18.3 \\
\hline
\end{tabular}




\begin{tabular}{|c|c|c|c|c|c|c|}
\hline \multirow[t]{2}{*}{ C no } & \multicolumn{2}{|c|}{ II } & \multicolumn{2}{|c|}{ III } & \multicolumn{2}{|c|}{ IV } \\
\hline & ${ }^{1} \mathrm{HNMR}$ & ${ }^{13} \mathrm{CNMR}$ & ${ }^{1} \mathrm{HNMR}$ & ${ }^{13} \mathrm{CNMR}$ & ${ }^{1} \mathrm{HNMR}$ & ${ }^{13} \mathrm{CNMR}$ \\
\hline \multicolumn{3}{|c|}{ Rhamnose-I } & \multicolumn{2}{|c|}{ Glucuronic Acid } & \multicolumn{2}{|l|}{ Glucose-I } \\
\hline 1 & 4.94 & 100.3 & $4.75 \mathrm{~d}(6.8)$ & 100.3 & $4.78 \mathrm{~d}(7.6)$ & 100.3 \\
\hline 2 & - & 70.6 & - & 72.8 & - & 72.7 \\
\hline 3 & - & 70.5 & - & 76.1 & - & 77.1 \\
\hline 4 & - & 74.6 & - & 77.8 & - & 71.0 \\
\hline 5 & - & 68.7 & - & 77.4 & - & 76.2 \\
\hline 6 & $1.66 \mathrm{~d}(6.9)$ & 17.9 & - & 170.8 & & 69.7 \\
\hline \multicolumn{3}{|c|}{ Rhamnose-II } & \multicolumn{2}{|l|}{ Rhamnose } & \multicolumn{2}{|l|}{ Glucose-II } \\
\hline 1 & 4.60 & 103.8 & 4.59 & 100.8 & $4.81 \mathrm{~d}(7.6)$ & 100.5 \\
\hline 2 & - & 70.6 & - & 70.9 & - & 72.7 \\
\hline 3 & - & 70.5 & - & 71.0 & - & 76.8 \\
\hline 4 & - & 74.6 & - & 75.0 & - & 71.0 \\
\hline 5 & - & 69.3 & - & 69.1 & - & 75.5 \\
\hline 6 & $\begin{array}{c}0.94(\mathrm{~d}, \\
J=6.8 \mathrm{~Hz})\end{array}$ & 17.9 & $1.09 \mathrm{~d}(5.9)$ & 18.3 & - & 60.2 \\
\hline \multicolumn{3}{|l|}{ Glucose } & \multicolumn{2}{|l|}{ Glucose-I } & \multicolumn{2}{|l|}{ Glucose-III } \\
\hline 1 & $\begin{array}{c}4.75(\mathrm{~d}, \\
J=8.4 \mathrm{~Hz})\end{array}$ & 99.9 & $4.76 \mathrm{~d}(7.6)$ & 100.4 & $4.76 \mathrm{~d}(7.6)$ & 100.7 \\
\hline 2 & & 72.4 & - & 72.8 & - & 72.7 \\
\hline 3 & - & 75.7 & - & 75.5 & - & 76.2 \\
\hline 4 & - & 77.5 & - & 77.6 & - & 71.0 \\
\hline 5 & - & 77.1 & - & 77.1 & - & 75.0 \\
\hline 6 & - & 59.9 & - & 60.2 & - & 60.7 \\
\hline \multicolumn{3}{|c|}{ Galactose } & \multicolumn{2}{|l|}{ Glucose-II } & & \\
\hline 1 & $\begin{array}{l}4.81(\mathrm{~d}, J \\
=8.5 \mathrm{~Hz})\end{array}$ & 100.1 & $4.81 \mathrm{~d}(7.6)$ & 100.6 & & \\
\hline 2 & - & 72.3 & - & 72.7 & & \\
\hline 3 & - & 75.1 & - & 75.0 & & \\
\hline 4 & - & 76.9 & - & 71.0 & & \\
\hline 5 & - & 76.7 & - & 76.8 & & \\
\hline 6 & - & 60.1 & - & 60.5 & & \\
\hline
\end{tabular}




\section{Discussion}

\section{Compound I;}

Weight is50 mg,On acid hydrolysis Compound (I) gave glucose, rhamnose and glucuronic acid in the aqueous phase (Co-TLC\& authentic sugar samples), the EI positive mass showed the fragmentation pattern of aglycone (sapogenin) ; which displayed prominent peaks at 234 (base peak), 219,201,187 and 176 due to molecular ion and rupture of ring $\mathbf{C}$ with other fragment at 161,147,133 and119 due to rupture of ring $B$ supporting the proposed structure of the compound, The ${ }^{13} \mathbf{C N M R}$ and DEPT spectra showed 30 carbon atoms attributed for aglycone part as seven methyl's at $\delta \mathrm{C}$ 22.3,15.3,14.2,15.4, 22.1,28.3 and 16.6; Characteristic for C23, 24, 25, 26, 27, 29 and 30 respectively, eight methylene at $\delta_{\mathrm{C}} 41.2,25.5,17.8,32.5,23.2,38.0,46.0$ and 59.8 assigned for $\mathrm{C} 1,2,6,7,11,15,19$ and 28 respectively, eight methin at 90.1, 55.1, 46.8, 121.6, 68.0, 44.5, $90.5 \& 74.0$ assigned for $\mathrm{C} 3,5,9,12,16,18,21$ and 22 respectively. Six quaternary carbons at $\delta_{\mathrm{C}} 36.9,41.6,35.8,42.8,43.0$ and 35.8 assigned for $\mathrm{C} 4,8,10,14,17 \& 20$ respectively and one Olifenic carbon at144.1 assigned for C13. The ${ }^{1}$ HNMR spectrum exhibited also, seven singlets, $3 \mathrm{H}$ each of seven methyls at $\delta_{\mathrm{H}} 1.29,0.75,0.88,0.85,1.79,1.06$ and 0.97 assigned for $\mathrm{H}-23,24,25,26,27,29$ and 30 respectively and also showed a characteristic brs, ${ }^{1} \mathrm{H}$ resonance at $\delta_{\mathrm{H}} 5.17$ assigned for $\mathrm{H}-12$ Olifenic protons together with another brs, ${ }^{1} \mathrm{H}$ resonance at 5.06 for $\mathrm{OH}-16$ and at 5.15 for $\mathrm{OH}-22$, from the previousdata expected the sapogenin part as olean-12-ene substituted by $\mathrm{OH}$ groups at $3 \beta, 16 \alpha, 21 \beta, 22 \alpha$ stereoisomer which is known as barringotogenol $\mathbf{C}$ and by comparison with previously reported data (Crublet M.L.et al;2002, Takao K.et al;1986) confirm the aglycone part as barringotogenol C.The ${ }^{1}$ HNMR spectrum of compound(I) displayed four anomeric proton signals at 4.76 $(\mathrm{d}, J=6.8 \mathrm{~Hz}), 4.80(\mathrm{~d}, J=6 \mathrm{~Hz}), 5.00 \mathrm{brs}$ and $4.94 \mathrm{brs}$ and four anomeric carbon signals at $\delta=99.9,100.1,100.3$ and 99.9 consequently compound (I)was assumed to possess four sugar units which were identified as glucoside, rhamnoside and glucouronic acid by comparison with authentic samples on TLC. The sugar linkages were determined by 2DNMR experiments. In the HMBC spectrum, long range correlation was observed between H-1 $\delta=5.00$ brs of rhamnose-II and C-21 $(\delta=90.5)$ of the aglycone, H-1 $(\delta=$ $4.76, \mathrm{~d}, J=6.8 \mathrm{~Hz})$ of glucuronic acid and C-3( $\delta=90.1)$ of the aglycone, $\mathrm{H}-1$ of glucose ( $\delta=4.80, \mathrm{~d}, J=6 \mathrm{~Hz})$ and $\mathrm{C}-4(\delta=77.4)$ of glucuronic acid, $\mathrm{H}-1(\delta=4.94 \mathrm{brs})$ of terminal rhamnose and C-4 of $(\delta=76.6)$ of glucose. From NMR data each sugar is a pyranosyl with $\beta$ configuration for glucosyl and glucuronic acid and $\alpha$ configuration for rhamnosyl. Therefore, the structure of compound (I) was assigned as 3-O$-[\alpha-\mathrm{L}-$ rhamnopyranosyl (1-4)- $\beta$-D-glucopyranosyl (1-4)- $\beta$-D-glucouronopyranoside] $21-\boldsymbol{O}$ - $\alpha$ L-rhamnopyranosidebarringotogenolC. 


\section{CompoundsII, III, IV;}

The a glycone parts of each of compound II,III \& IVexpected as barringotogenol $\mathrm{C}$ in comparison with the previous reported data and data of compound I confirmed it but the glycone parts are differ for each one.On complete acid hydrolysis ofcompound II gave glucose, galactose, rhamnose in aqueous phase (CoTLC\& authentic sugar samples). Two $\beta$-anomeric protons were assigned at $4.75 \mathrm{~d}(8.4)$ and $4.81 \mathrm{~d}(8.5)$ beside with two anomeric $\alpha$-type protons at 4.94brs and 4.60brs with Methyl proton at $1.66 \mathrm{~d}(6.9) \& 0.94 \mathrm{~d}$ (6.8) together with four anomeric carbon resonance at 103.8, 100.3, 100.1 and 99.9.The most downfield carbon resonance at 103.8 expected for rhamnose moiety at C-21, as well as the downfield shift of C-4 of galactose to $76.9(\Delta \approx+7 \mathrm{ppm})$ and $\mathrm{C}-4$ of glucose at $77.5(\Delta \approx+7 \mathrm{ppm})$, from all the previous data $\&$ in comparison with compound (I)identification of compound (II)according to(Crublet M.L.et $\quad \boldsymbol{a l} ; 2002)$ as3-O-[ $\alpha$-L-rhamnopyranosyl(1-4)- $\beta$ glucopyranosyl(1-4)- $\beta$-D-galactopyranosyl]21-O- $\alpha$ -

Lrhamnopyranosidebarringotogenol C.On complete acid hydrolysis Compound(III); gave glucose, rhamnose, glucuronic acid in aqueous phase (CoTLC\& authentic sugar samples). Three $\beta$ anomeric protons were assigned at $4.75 \mathrm{~d}(\mathrm{~J}=7.6 \mathrm{~Hz})$, $4.79 \mathrm{~d}(\mathrm{~J}=6.8 \mathrm{~Hz})$ and $4.81 \mathrm{~d}(\mathrm{~J}=7.6 \mathrm{~Hz})$ which were expected for a linear triglycosidic residue on $\mathrm{C}$-3 due to the assignment of its ${ }^{13} \mathrm{C}$-signal downfield at 90.5 (Crublet M.L.et al;2002). The $\delta$ values of three anomeric carbons at 100.3, 100.4,100.6 assigned for glucuronic acid,glucoseI,glucoseII respectively, due to the downfield shiftof C-4 of glucuronic acid to $77.8(\Delta \approx+7 \mathrm{ppm})$ and C-4 of glucose-I to 77.6 $(\Delta \approx+7 \mathrm{ppm})$, additionally the up field of $\alpha$-anomeric proton were assigned at $4.59 \mathrm{brs}$ assigned for rhamnose moiety with 6-methyl group at $1.09 \mathrm{~d}(J=5.9 \mathrm{~Hz}) \&$ the most downfield anomeric carbon at 100.8 and methyl rhamnose at 18.3 , from the previous data compound (III)was defined as3-O -[ $\beta$-D-glucopyranosyl (1-4)- $\beta$-D-glucopyranosyl (1-4) - $\beta$-D glucuronopyranoside] 21- $\boldsymbol{O}$ - $\alpha$-L-rhamnopyranosidebarringotogenol C.On complete acid hydrolysis compound(IV)gave glucose in aqueous phase, three $\beta$ anomeric protons were assigned at 4.81,4.78 and 4.76 each doublet with $J$ value equal 7.6 $\mathrm{Hz}$ confirmed with three anomeric carbon resonance at 100.5, 100.3,100.7 characteristic for three glucose moieties, the most upfield proton \& downfield carbon assigned for $\beta$-glucopyranosyl moiety at C-21 and the other two glucose units attached at C-3 aglycone the interglycosidic linkage of both two glucose units expected (1-6) due to the downfield shift of C-6 of glucose (glucose-II to 69.7 ( $\Delta \approx+7-8 \mathrm{ppm}$ ). (Crublet M.L.et al;2002)(Schmid TJet al;2004), accordingly compound (IV) was

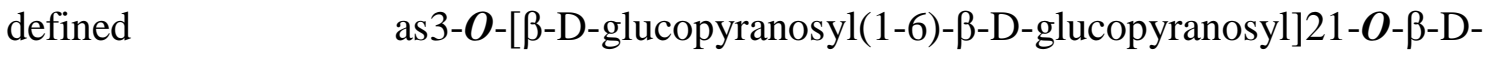
glucopyranoside barringotogenol $\mathbf{C}$. 


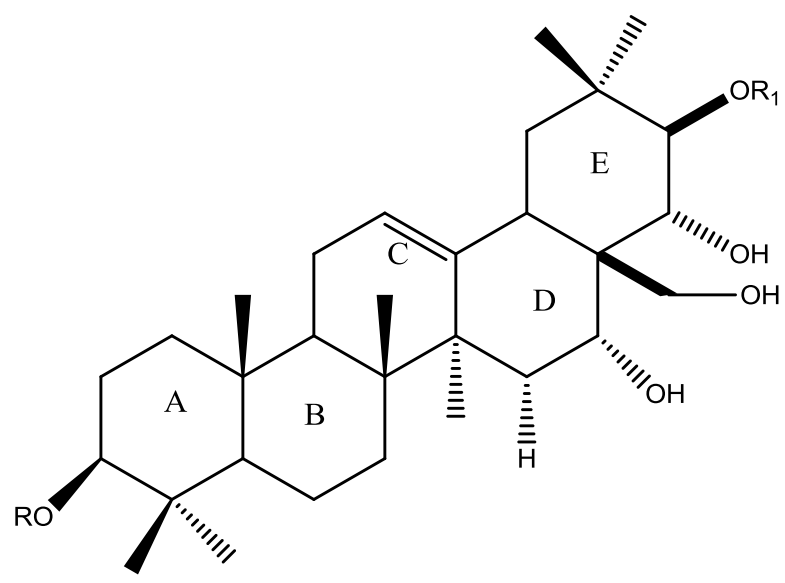

Fig(1) Structures of the isolated compound

\begin{tabular}{|c|c|c|}
\hline & $\mathbf{R}$ & $\mathbf{R}_{1}$ \\
\hline $\mathbf{I}$ & $\begin{array}{l}\alpha \text {-L-rhamnopyranosyl(1-4)- } \beta \text {-D-glucopyranosyl(1-4)- } \\
\beta \text {-D-glucopyranoside }\end{array}$ & $\alpha$-L-Rhamnose \\
\hline II & $\begin{array}{l}\alpha \text {-L-rhamnopyranosyl(1-4)- } \beta \text {-glucopyranosyl(1-4)- } \beta \text { - } \\
\text { D-galactopyranosyl }\end{array}$ & $\alpha$-L-Rhamnose \\
\hline III & $\begin{array}{l}\beta \text {-D-glucopyranosyl (1-4)- } \beta \text {-D-glucopyranosyl (1-4) - } \\
\beta \text {-D glucuronopyranoside }\end{array}$ & $\alpha$-L-Rhamnose \\
\hline IV & $\beta$-D-glucopyranosyl(1-6)- $\beta$-D-glucopyranosyl & $\beta$-D-Glucose \\
\hline
\end{tabular}

\section{Biological Studies}

A wide range of biological activities have been reported for alfalfa plant due to the structure diversity of its phytochemical constituents. In this genus, the aerial parts, roots, flowers, leaves, stem \& sprout of the different Medicago species have been reported as potent anti-inflammatory,(it is well used against rheumatoid arthritis, rheumatism and gout) (Chen L.2015), hepatoprotective(Xie Z. et al; 2008\& AlDosariMS 1 2012).Cancer chemoprotective therapy (Rosenthal G.A. et al;2011), Antibacterial activity against bothgram negative \& positive bacterial(Sabrine K. et al;2015)

\section{Antimicrobial Susceptibility testing}

Antimicrobial tested compound preparation.100 ul of tested compounds solution prepared by dissolving $10 \mathrm{mg}$ of the isolated pure chemical compounds, methanol \& dichloromethane extracts in $1 \mathrm{ml}$ (DMSO used as negative control) 
Amphotericin B, Ampicillin and Ciprofloxacin were used as standards for Gram positive \&Gram negative and Fungi respectively

\section{Inoculum Preparation}

Inoculum was prepared as saline suspension of isolated colonies selected from 24 hours at $37^{\circ} \mathrm{C}$ for bacteria, 48 hours at $28^{\circ} \mathrm{c}$ for fungi. The suspension is adjusted to match the 0.5 MCFarland turbidity standards using a vortex mixer and using saline as standard.

\section{Cups plate Method}

A lawn culture was produced in Müeller-Hinton agar plates. Six cubs were made on the petridishes and $100 \mathrm{ul}$ aliquots of extracts were pipetted on. The plates were left for 1 hour at room temperature and then incubated at $37^{\circ} \mathrm{c}$ for 48 hours. Plates were examined for inhibition zones of the growth of bacteria and fungi around the extracts. The averages of those zones were recorded in millimeters. The experiment was carried out in triplicate and average zone of inhibition \pm SD were calculated (SmâniaA.et al;1999).

\section{Minimum inhibitory concentration (MIC)}

The broth microdilution method was used to determine MIC. All tests were performed in Mueller Hinton Broth supplemented with Tween 80 at a final concentration of $0.5 \%(\mathrm{v} / \mathrm{v})$. Briefly, serial doubling dilutions of the compounds were prepared in a 96-well microliter plate ranged from $1000 \mathrm{ug} / \mathrm{ml}$ to $0.24 \mathrm{ug} / \mathrm{ml}$. To each well, $10 \mu \mathrm{l}$ of indicator solution and $10 \mu \mathrm{l}$ of Mueller Hinton Broth were added. Finally, $10 \mu \mathrm{l}$ of bacterial suspension $\left(10^{6} \mathrm{CFU} / \mathrm{ml}\right)$ was added to each well to achieve a concentration of $10^{4} \mathrm{CFU} / \mathrm{ml}$. The plates were wrapped loosely with cling film to ensure that the bacteria did not get dehydrated. The plates were prepared in triplicates, and then they were placed in an incubator at $37^{\circ} \mathrm{C}$ for $18-24$ hours. The microorganism growth was indicated by turbidity. The MIC is defined as the lowest concentration of the extract at which the microorganism does not demonstrate visible growth. 
Table(3):

Mean zone of inhibition in $\mathrm{mm} \pm$ Standard deviation produced on a range of pathogenic microorganisms using (10 mg/ml) concentration of tested samples.

\begin{tabular}{|c|c|c|c|c|c|c|c|}
\hline Tested & Methanol extract & $\begin{array}{c}\text { chloroform } \\
\text { extract }\end{array}$ & $I$ & II & III & $I V$ & Standard drug \\
\hline Fungi & & & & & & & Amphotericin B \\
\hline$\overline{\text { Aspergillus fumigatus }}$ & $17.3 \pm 0.58$ & $12.1 \pm 1.2$ & $16.9 \pm 0.63$ & $13.3 \pm 1.3$ & $16.1 \pm 0.63$ & NA & $23.7 \pm 1.2$ \\
\hline Candida albicans & $15.2 \pm 1.2$ & $10.3 \pm 0.58$ & $19.1 \pm 0.58$ & $15.2 \pm 2.1$ & $18.3 \pm 0.36$ & NA & $25.4 \pm 0.58$ \\
\hline Gram Positive Bacteria: & & & & & & & Ampicillin \\
\hline Streptococcus pneumoniae & $19.2 \pm 1.6$ & $11.3 \pm 1.5$ & $19.3 \pm 1.5$ & $17.4 \pm 1.5$ & $18.9 \pm 0.67$ & NA & $23.8 \pm 1.2$ \\
\hline Staphylococcus aureus & $16.5 \pm 0.63$ & $10.6 \pm 0.63$ & $17.9 \pm 1.2$ & $14.6 \pm 1.2$ & $17.3 \pm 0.56$ & NA & $27.4 \pm 0.72$ \\
\hline Gram negative Bacteria: & & & & & & & Ciprofloxacin \\
\hline Pseudomonas aeruginosa & $13.3 \pm 0.23$ & $9.2 \pm 0.58$ & $16.8 \pm 1.3$ & $15.4 \pm 0.53$ & $16.2 \pm 0.72$ & NA & $20.6 \pm 1.2$ \\
\hline Escherichia coli & $15.3 \pm 1.5$ & $12.1 \pm 1.5$ & $19.9 \pm 0.72$ & $19.3 \pm 0.72$ & $19.3 \pm 1.5$ & NA & $23.4 \pm 0.63$ \\
\hline
\end{tabular}


Table(4): Antimicrobial Activity as MICS ( $\mu \mathrm{g} / \mathrm{ml}$ ) of tested samples against tested microorganisms

\begin{tabular}{|c|c|c|c|c|c|c|c|}
\hline Sample & $\begin{array}{c}\text { Methanol } \\
\text { extract }\end{array}$ & $\begin{array}{c}\text { chloroform } \\
\text { extract }\end{array}$ & $I$ & II & III & $I V$ & Standard drug \\
\hline & \multicolumn{6}{|c|}{ Minimum inhibitory concentration $(\mu \mathrm{g} / \mathrm{ml})$} & \\
\hline$\underline{F U N G I}$ & & & & & & & Amphotericin B \\
\hline Aspergillus fumigatus & 15.63 & 125 & 31.25 & 62.5 & 31.25 & NA & 0.98 \\
\hline Candida albicans & 62.5 & 250 & 7.81 & 62.5 & 7.81 & NA & 0.49 \\
\hline Gram Positive Bacteria: & & & & & & & Ampicillin \\
\hline $\begin{array}{l}\text { Streptococcus } \\
\text { pneumoniae }\end{array}$ & 3.9 & 250 & 3.9 & 15.63 & 3.9 & NA & 0.98 \\
\hline Staphylococcus aureus & 31.25 & 250 & 15.63 & 31.25 & 15.63 & NA & 0.49 \\
\hline Gram negative Bacteria: & & & & & & & Ciprofloxacin \\
\hline Pseudomonas aeruginosa & 62.5 & 250 & 31.25 & 31.25 & 31.25 & NA & 1.95 \\
\hline Escherichia coli & 31.25 & 125 & 3.9 & 3.9 & 3.9 & NA & 0.49 \\
\hline
\end{tabular}




\section{Discussion of Antimicrobial Activity}

Methanolic extract showed the highest antimicrobial activity while chloroform extract showed moderate activity against test organism as in Table (3). We completed the work of separation and purification bioguided. Hence we have made Antimicrobial test of the four isolated triterpene saponin compounds from the methanolic extract of alfalfa aerial part. The Antimicrobial activities of isolated compounds were evaluated against tested organism, the results showed that compound (IV) had no Antimicrobial activity against microorganisms assayed, on the other hand compound (I), (II) and (III) showed an interesting antimicrobial activity for all tested strains as inTable (3). The current study illustrated in Table (4) that dichloromethan extract has the maximum inhibition. While compound (II), revealed minimum inhibitory concentration against Candida albicans, Staph aureus and E coli.

\section{In vitro Anti-Diabetic Assay}

\section{$\alpha$-Amylase inhibition method}

A total of $500 \mu \mathrm{l}$ of test samples and acarbose $(1000-7.81 \mu \mathrm{g} / \mathrm{ml})$ were added to $500 \mu 1$ of $0.20 \mathrm{mM}$ phosphate buffer ( $\mathrm{pH} 6.9$ ) containing $\alpha$-amylase $(0.5 \mathrm{mg} / \mathrm{ml}$ ) solution and were incubated at $25^{\circ} \mathrm{C}$ for $10 \mathrm{~min}$. After these, $500 \mu \mathrm{l}$ of a $1 \%$ starch solution in $0.02 \mathrm{M}$ sodium phosphate buffer ( $\mathrm{pH}$ 6.9) was added to each tube. The reaction mixtures were then incubated at $25^{\circ} \mathrm{C}$ for $10 \mathrm{~min}$. The reaction was stopped with $1.0 \mathrm{ml}$ of 3,5 dinitro-salicylic acid color reagent. The test tubes were then incubated in a boiling water bath for $5 \mathrm{~min}$, cooled to room temperature. The reaction mixture was then diluted after adding $10 \mathrm{ml}$ distilled water and absorbance was measured at $540 \mathrm{~nm}$. Control represent $100 \%$ enzyme activity and were conducted in similar way by replacing extracts with water. All determinations were carried out in triplicate manner and values \& expressed as the mean \pm SD. The IC50 value was defined as the concentration of sample to inhibit $50 \%$ of $\alpha$-Amylase under the assay conditions. 

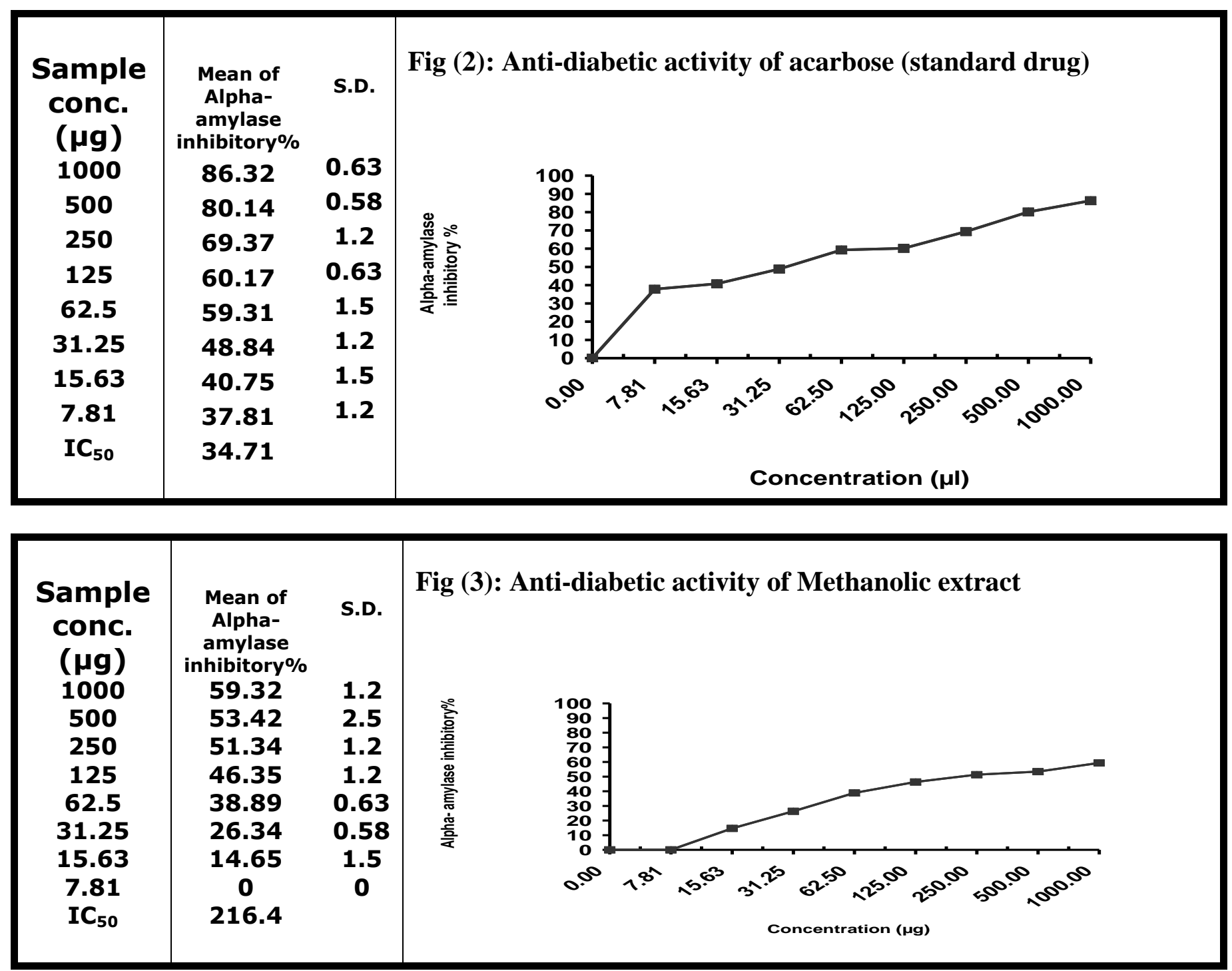


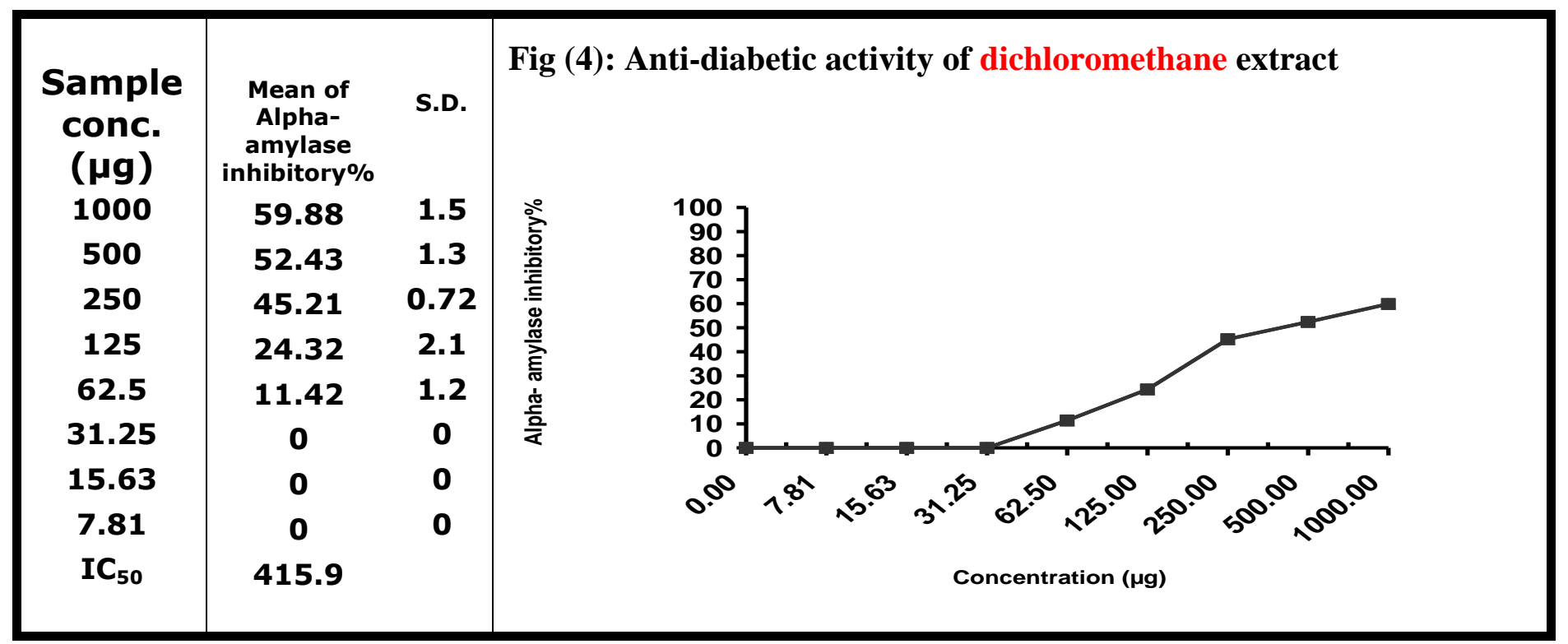

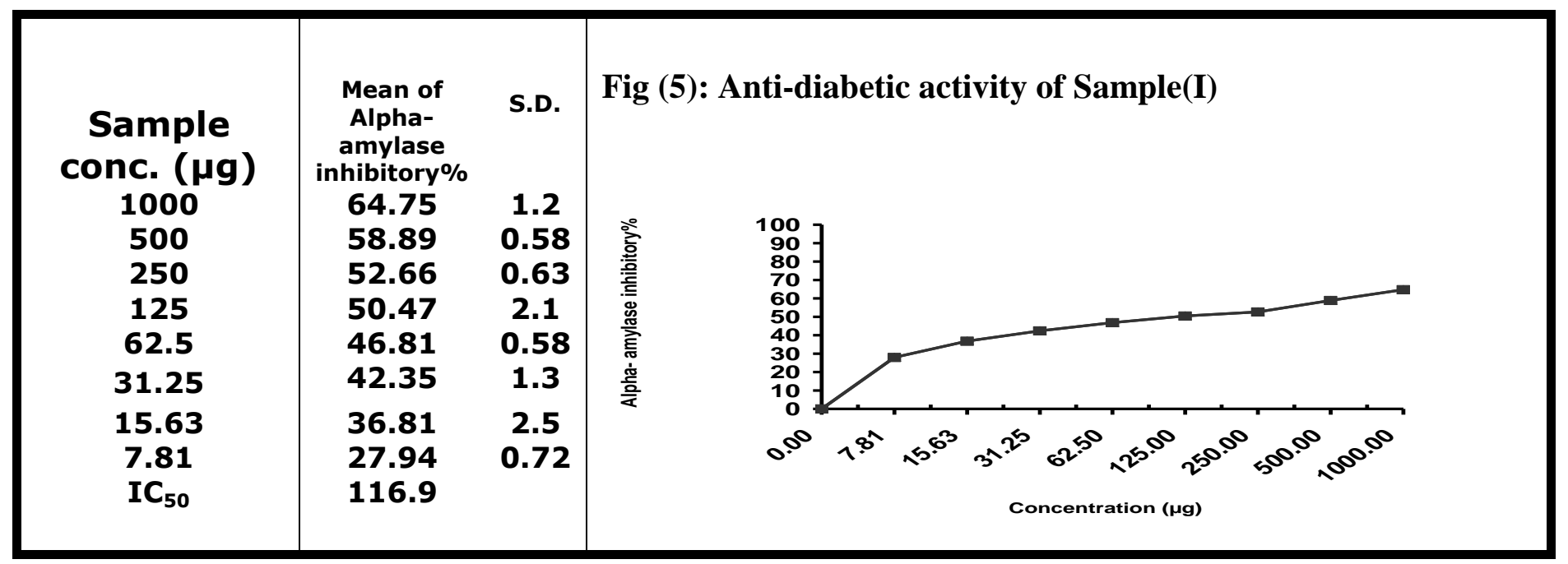




\begin{tabular}{|c|c|c|c|}
\hline $\begin{array}{l}\text { Sample conc. } \\
(\mu \mathrm{g}) \\
1000 \\
500 \\
250 \\
125 \\
62.5 \\
31.25 \\
15.63 \\
7.81 \\
\mathrm{IC}_{50}\end{array}$ & \begin{tabular}{|l} 
Mean of \\
Alpha- \\
amylase \\
inhibitory\% \\
60.35 \\
54.32 \\
52.14 \\
47.63 \\
31.25 \\
21.31 \\
16.35 \\
8.34 \\
190.7
\end{tabular} & $\begin{array}{l}\text { S.D. } \\
\\
1.5 \\
2.1 \\
0.72 \\
0.63 \\
1.2 \\
0.72 \\
1.2 \\
1.5\end{array}$ & 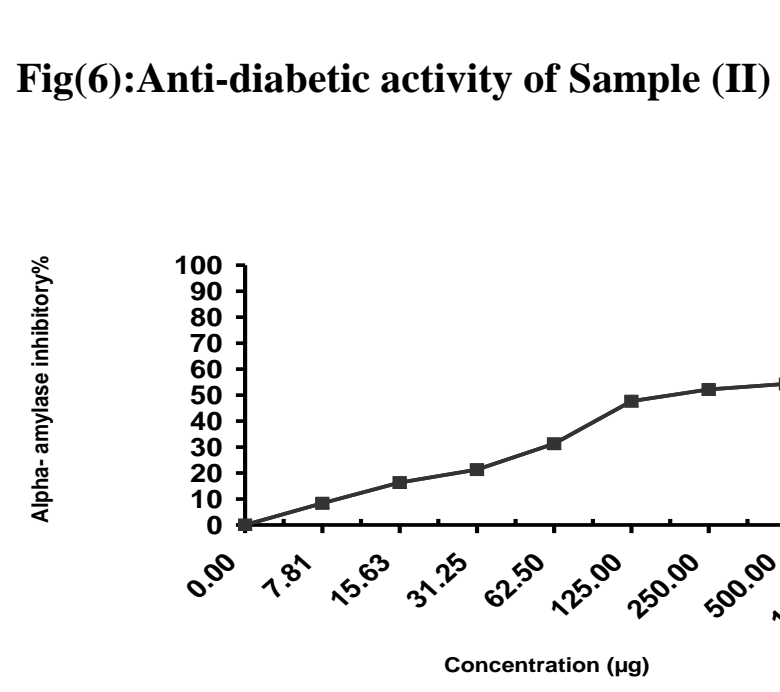 \\
\hline
\end{tabular}

\begin{tabular}{|c|c|c|c|}
\hline $\begin{array}{l}\text { Sample conc. }(\boldsymbol{\mu g}) \\
1000 \\
500 \\
250 \\
125 \\
62.5 \\
31.25 \\
15.63 \\
7.81 \\
1 C_{50}\end{array}$ & $\begin{array}{l}\text { Mean of } \\
\text { Alpha- } \\
\text { amylase } \\
\text { inhibitory\% } \\
69.32 \\
59.31 \\
56.81 \\
41.37 \\
22.35 \\
14.68 \\
9.35 \\
0 \\
194.9\end{array}$ & $\begin{array}{l}\text { S.D. } \\
\\
1.4 \\
1.8 \\
1.5 \\
0.72 \\
1.3 \\
0.72 \\
1.2 \\
0\end{array}$ & 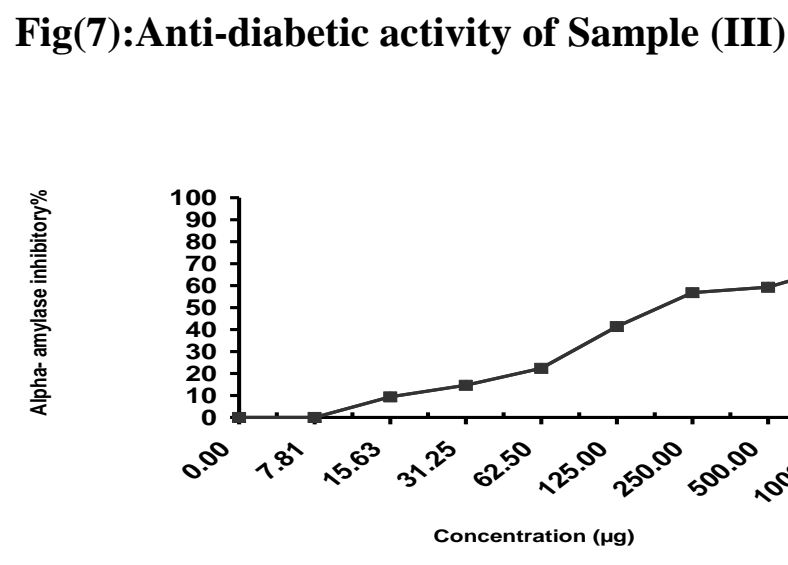 \\
\hline
\end{tabular}




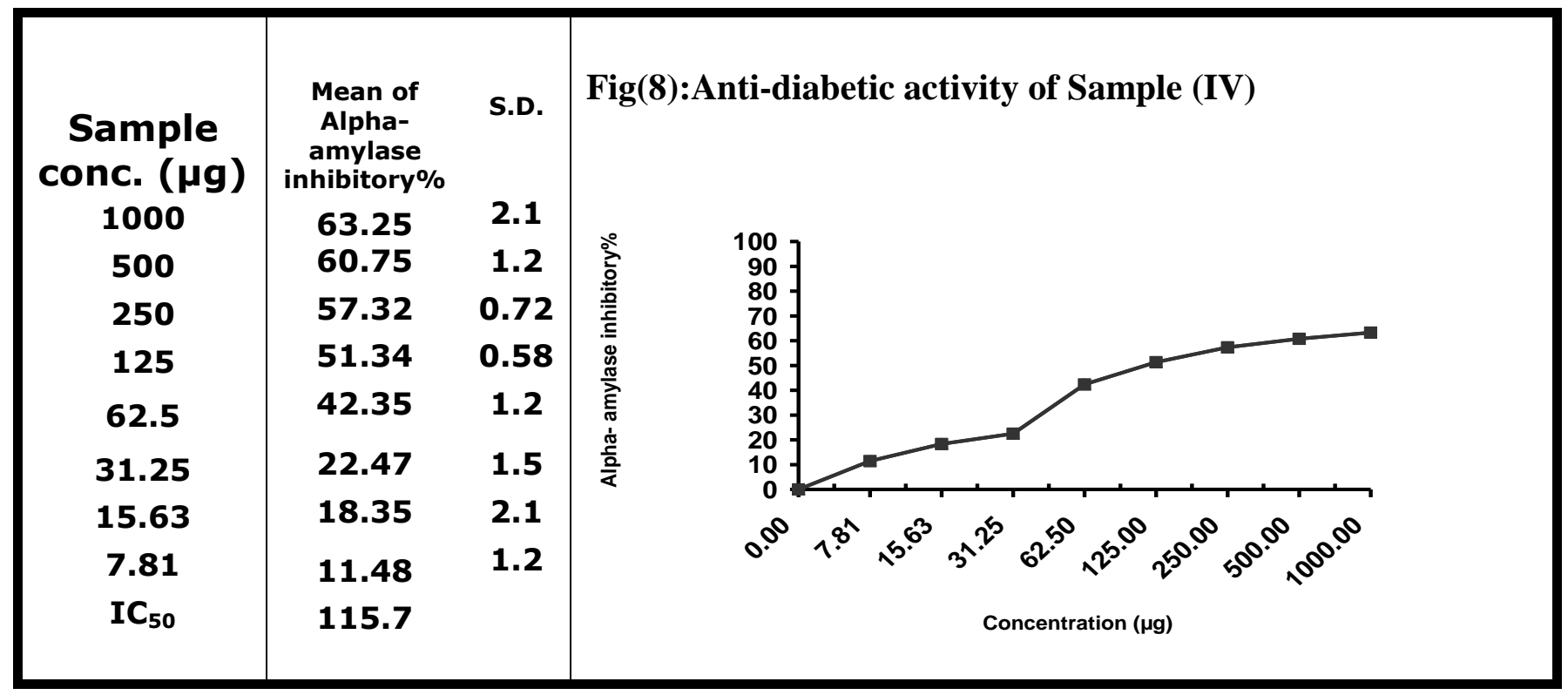

\section{Discussion}

In accordance with the previous studies and examination, the Anti-Diabetic activity of aerial part extracts of alfalfa was tested against $\alpha$-amylase enzyme Fig (2-8).In general methanolic extract exhibited promising inhibition percentage in comparison with dichloromethane extract under these screening conditions. The current study illustrated that, the most promising Anti-Diabetic effect was compound (IV), which had the least $\mathrm{IC}_{50}$. 


\section{REFERENCES}

Al-Dosari M.S. (2012).In vitro and in vivo antioxidant activity of alfalfa (Medicago sativa L.) on carbon tetrachloride intoxicated rats. Pub Med. gov, vol.(4), p. 779-793.

Benson. (1965).Plant Classification.p. 244-247. Oxford.

Chen L., Liu J., Zhang Y., Dai B., An y. and Yu Il. (2015).Structural, thermal \& antiinflammatory properties of a novel pectic polysaccharide from alfalfa (Medicago sativa L.) stem. Pub Med.gov, vol. (63), Issue (12), p. 3219-3228.

Crublet M. L., Pouny I., Delaude C. and Lavaud C. (2002).Acylatedtriterpernoidsaponins from the stem of foetdiaafricane.J. Nat. Prod, vol. (65), p. 1560-1567.

Duke J.A. (1985). Hand Bookof Medicinal Herbs. J.A. Boca Raton, Florida, U.S.A. p. 299300

Rathee P., Chaudhary H., Rathee S., Rathee D., Kumar V. and Kohli K. (2009). Mechanism of Action of flavonoids as Anti-inflammatory agents: A Review. Pub Med. gov, vol. (8), Issue (3), p. 229-235.

Rosenthal G.A. and NKomo P.(2011). The Natural Abundance of L. Canavanine, An Active Anti-Cancer Agent in Alfalfa, Medicago sativa L. Research gate.com, vol. (38), Issue (1), p. 1-6.

Sabrine K., Bougatef A., Chataign G. and Guillsu Me le flem.(2015).Anti-bacterial activity of novel peptides isolated from protein hydrolysates of Rubisco purified from green juice (alfalfa). AGRIS, vol.(18), p. 703-713.

Schmidt TJ.Von R. J. and Willuhn G. (2004). New triterpene esters from flower heads of Arnica lonchophylla.Planta Med, vol. (70), p. 967-977.

Smânia A., Monache F.D., Smania E.F.A. and Cuneo R.S. (1999). Antibacterial activity of steroidal compounds islolated from Ganodermaapplanatum (pers.) pat. Aphyllophoromycetideae fruit body.Int. J. Med. Mushrooms, vol. (1), p. 325-330.

Takao K. and lec k. H. (1986). J. Nat. prod, Vol.(49), Issue (4), p.p. (561-744)

Xie Z., Huang J., Xu X. and Jin Z.(2008).Antioxidant activity of peptides isolated from alfalfa leaf protein hydrolysate. Food chemistry, vol.(111), Issue(2), p. 370-376 


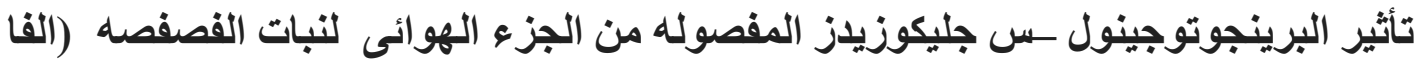

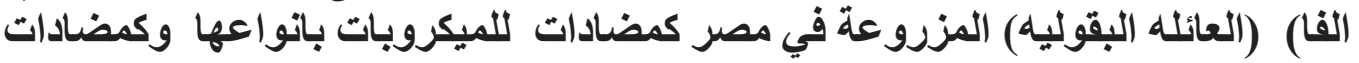
للسكري مير كمدي

للسادة الاكاتزة

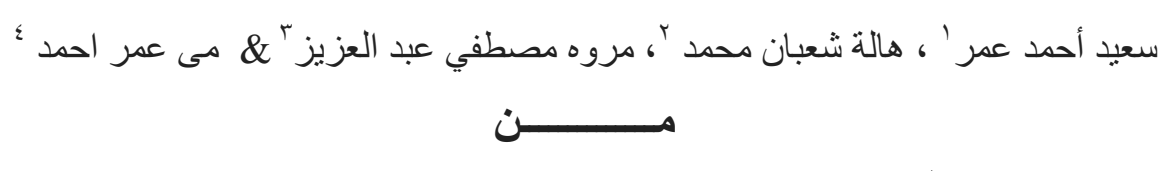

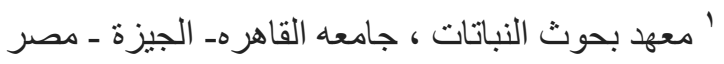

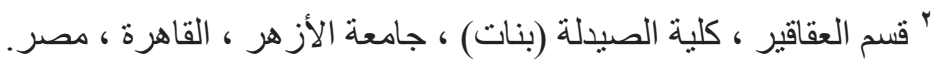

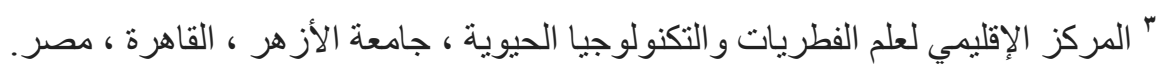

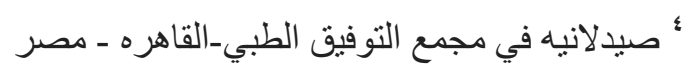

ملخص البحث

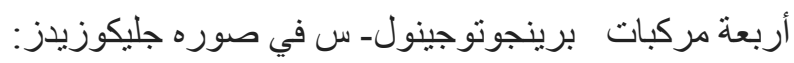

3-O-[ $\alpha$-L-rhamnopyranosyl (1-4) $\quad \beta$-D- glucopyranosyl $\quad(1-4) \quad \beta$-Dglucouronopyranoside] 21-O- $\alpha$-L-rhamnopyranoside barringotogenol $\mathbf{C}$ (I), 3- $O$ - $[\alpha-\mathrm{L}-$ rhamnopyranosyl (1-4) $\beta$-glucopyranosyl (1-4) $\beta$-D-galactopyranosyl] 21-O- $\alpha$-Lrhamnopyranoside barringotogenol $\mathbf{C}$ (II), 3-O-[ $\beta$-D-glucopyranosyl (1-4) $\beta$-Dglucopyranosyl (1-4) $\quad \beta$-D glucuronopyranoside] 21-O- $\alpha$-L-rhamnopyranoside barringtogenol C (III), 3-O-[ $\beta$-D-glucopyranosyl (1-6) $\beta$-D-glucopyranosyl] 21-O- $\beta$ D-glucopyranoside barringtogenol C (IV), الفصفصه . تم تعريف جميع المركبات الاربعه المفصوله عن طريق الرنين المغناطيسي (1D\&2D )

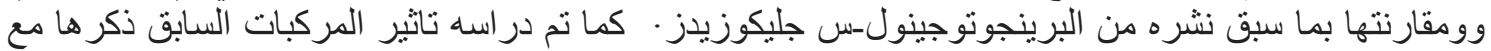

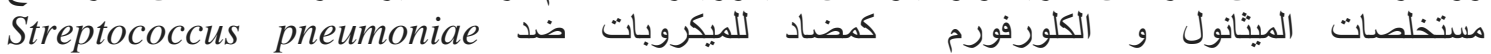

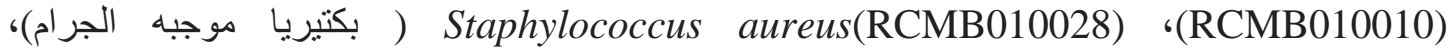
Escherichia coli(RCMB010052) ، 'Pseudomonas aeuroginosa (RCMB010043) سالبه الجرام والنشاط المضاد للفطر ضد (RCMB02568) وAspergillus fumigatus (Randida

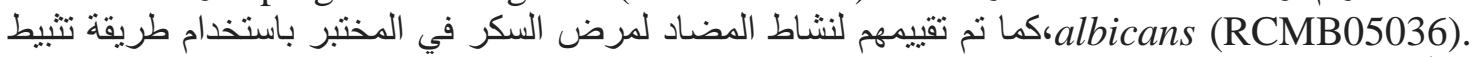

